\title{
Pengaruh Suplementasi Seng dan Probiotik Terhadap Kejadian Diare Berulang
}

\author{
Hani Purnamasari, ${ }^{*}$ Budi Santosa, ${ }^{*}$ Niken Puruhita** \\ ${ }^{*}$ Bagian Ilmu Kesehatan Anak Fakultas Kedokteran Universitas Diponegoro/RSUP Dr. Kariadi, \\ Semarang \\ ** Bagian Ilmu Gizi Klinik Fakultas Kedokteran Universitas Diponegoro/RSUP Dr. Kariadi, Semarang
}

Latar belakang. Angka kesakitan diare pada balita di negara berkembang masih tinggi. Pada beberapa penelitian terbukti efek seng dan probiotik masing masing dalam mencegah diare dapat menurunkan angka kejadian. Namun pemberian secara bersamaan belum banyak diketahui.

Tujuan. Membuktikan pengaruh suplementasi seng dan probiotik secara bersamaan pasca perawatan diare akut pada anak terhadap kejadian diare berulang.

Metode. Penelitian kohort prospektif lanjutan Studi I "Pengaruh suplementasi seng dan probiotik terhadap durasi diare akut cair anak", selama 3 bulan. Subjek adalah 75 anak usia 6-24 bulan pasca rawat diare akut cair di RS Dr. Kariadi Semarang. Pengelompokkan dilakukan secara acak menjadi 4 kelompok, kelompok I hanya mendapat terapi baku tanpa suplementasi, kelompok II mendapat suplementasi seng, kelompok III diberikan suplementasi probiotik, dan kelompok IV kombinasi seng-probiotik. Setiap kelompok mendapat terapi baku, rehidrasi, dan dietetik. Uji statistik menggunakan analisis kesintasan untuk mengetahui kejadian diare berulang, uji Kruskal Wallis untuk perbedaan frekuensi dan lama diare.

Hasil. Kelompok suplementasi seng- probiotik bersamaan memiliki rerata survival diare berulang terlama yaitu 10,94 minggu (CI 95\% 9,24 -12,65), dibanding kelompok lainnya, meskipun secara statistik tidak berbeda bermakna $(p=0,892)$. Frekuensi maupun lama diare berulang keempat kelompok pada bulan pertama, kedua dan ketiga pasca suplementasi secara statistik tidak berbeda bermakna.

Kesimpulan. Pemberian suplementasi seng- probiotik bersamaan berpengaruh dalam memberikan rerata perlindungan terhadap terjadinya diare berulang lebih lama. Tidak terdapat perbedaan bermakna dalam rerata survival diare berulang, lama dan frekuensi diare berulang di antara keempat kelompok. Sari Pediatri 2011;13(2):96-104.

Kata kunci: suplementasi seng, probiotik, diare berulang

\footnotetext{
Alamat korespondensi:

Dr. Hani Purnamasari. Bagian Ilmu Kesehatan Anak RS.Dr.Kariadi Semarang Jl. Dr.Sutomo no.18 Semarang.

E-mail: hani_purnamasari@yahoo.com
}

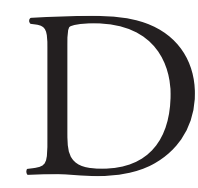
iare masih merupakan masalah kesehatan utama pada anak terutama balita di negara berkembang karena angka kesakitan dan kematian yang tinggi. Sekitar $80 \%$ kematian karena diare terjadi pada anak di bawah 
dua tahun. Di Indonesia terdapat kecenderungan peningkatan kejadian diare, 1.078 (1996) menjadi 1278 per 1000 anak (2000). Pada tahun 2003 diperkirakan 8 dari 10 kematian terjadi pada anak di bawah 2 tahun dengan angka kesakitan diare 374 per 1.000 penduduk dan episode pada balita 1,08 kali per tahun. ${ }^{1,2}$ Pasien diare di kota Semarang 29.943, per tahun dan sepertiganya adalah balita. ${ }^{3}$

Penyebab diare akut multifaktorial, namun sebagian besar disebabkan oleh infeksi. Kerusakan mukosa usus dengan derajat ringan maupun berat, membutuhkan waktu untuk kembali normal. Diare yang baru sembuh, pada sebagian kasus dapat kambuh atau berulang kembali akibat penyembuhan kurang sempurna, infeksi menetap, reinfeksi patogen lain ataupun gangguan penyerapan. ${ }^{4,5}$

Terapi rehidrasi efektif menurunkan angka kematian akibat diare, namun pencegahan diare tetap diperlukan dalam menurunkan tingginya kejadian. ${ }^{6}$ Pengelolaan diare cair akut menurut Kementrian Kesehatan adalah penggantian cairan dan elektrolit, tetap memberikan makan selama diare serta pemberian antibiotik dan antiparasit pada kasus-kasus tertentu. ${ }^{7}$ Rekomendasi WHO (2005) adalah pengggunaan cairan rehidrasi oral osmolaritas rendah dan suplementasi seng selama 10-14 hari. ${ }^{6,8}$ Sedangkan Unit Koordinasi Kerja Gastro-hepatologi Ikatan Dokter Anak Indonesia (UKK Gastro-Hepatologi IDAI) memperkenalkan lima lintas tata laksana pada diare, meliputi rehidrasi, dukungan nutrisi, suplementasi seng, antibiotik selektif, dan edukasi orang tua. ${ }^{9}$

Seng berperan dalam proses reepitelialisasi kerusakan mukosa akibat diare serta terbukti aman dan efektif dalam pengobatan diare, termasuk penggunaan jangka panjang. ${ }^{10}$ Terapi seng berguna untuk pengobatan baik diare akut maupun persisten, serta sebagai profilaksis. ${ }^{11}$ Di Indonesia, Hidayat ${ }^{12}$ melaporkan episode diare lebih tinggi pada kelompok seng (hazard ratio : 0,89, 95\%CI $(0,82-0,97))$. Sedangkan Bhandari ${ }^{13}$ di India mendapatkan sebagian besar anak pada kelompok seng tidak mengalami episode diare kembali selama masa pengamatan dibandingkan kelompok plasebo (RR 1,22; 95\%CI: 1,02-1,44). Sementara itu Endang-Purwaningsih ${ }^{14}$ menemukan laju insidens diare dari kelompok suplementasi seng lebih rendah dibandingkan kelompok kontrol. Lukacik ${ }^{15}$ melakukan studi metaanalisis, menyimpulkan bahwa tidak didapat manfaat yang diharapkan dari pemberian suplementasi seng pada diare akut terhadap lama diare.
Probiotik telah banyak digunakan dalam pengelolaan diare saat ini. Probiotik berperan saat terjadi gangguan keseimbangan bakteri probiotik atau disbiotik, mukosa usus lebih mudah terserang bakteri patogen penyebab diare. ${ }^{16,17}$ Saavedra $\mathrm{dkk}^{18}$ melaporkan bahwa secara signifikan kasus diare akut ditemukan lebih sedikit pada kelompok probiotik ( $\mathrm{p}=0,035)$. Sazawal dkk, ${ }^{19}$ membuktikan probiotik mengurangi risiko diare akut pada anak 57\% dan 26\% pada dewasa. McFarland $\mathrm{dkk}^{20}$ dalam suatu metaanalisis menyimpulkan probiotik mengurangi frekuensi diare secara signifikan dibanding kontrol $(\mathrm{RR}=0,39,95 \%$ CI $0,27,0,55, \mathrm{z}=5,3, \mathrm{p}<0,0001)$. Metaanalisis peran probiotik pada diare oleh Van $\mathrm{Niel}^{21}$ menyebutkan lactobacillus aman dan efektif sebagai pengobatan diare akut karena infeksi pada anak.

Penelitian yang membandingkan efektifitas kombinasi suplementasi seng dan probiotik pada anak dalam mengurangi kejadian berulangnya diare akut belum banyak dilakukan. Penambahan probiotik, seng, dan plasebo pada diet bayi usia 6-12 bulan dilakukan oleh Shamir $^{22}$ di Israel, terbukti secara signifikan mengurangi derajat berat dan lama diare akut pada kelompok perlakuan. Agustina $\mathrm{dkk}^{23} \mathrm{di}$ Indonesia pemberian suplementasi diet berupa susu formula mengandung probiotik, prebiotik dan serat mikronutrien (seng dan besi) pada anak usia 3-12 bulan dilaporkan mengalami lama diare lebih pendek, dan penambahan berat badan selama pengobatan meskipun tidak signifikan.

Penelitian kami merupakan lanjutan suplementasi seng dan probiotik terhadap efek serta durasi diare. Kejadian diare setelah suplementasi bila diberikan secara tersendiri atau bersamaan pada diare cair akut akan kami amati.

\section{Metode}

Telah dilakukan penelitian follow-up selama tiga bulan dari penelitian sebelumnya (studi I) dengan judul " pengaruh suplementasi seng dan probiotik terhadap durasi diare akut cair anak" menggunakan metode kohort prospektif, di Sub Bagian Gastroenterologi bagian Ilmu Kesehatan Anak Fakultas Kedokteran Universitas Diponegoro / RS Dr. Kariadi Semarang dan Kabupaten Semarang. Subyek dikelompokkan menjadi empat, yaitu kelompok I (mendapat terapi baku, tanpa suplementasi), kelompok II (mendapat 
terapi baku dan suplementasi seng), kelompok III (mendapat terapi baku dan suplementasi probiotik), kelompok IV (mendapat terapi baku dan suplementasi seng serta probiotik). Setiap kelompok mendapat terapi rehidrasi dan dietetik sesuai ketentuan. Kunjungan rumah dilakukan untuk mendapatkan data kejadian diare pasca suplementasi, kemudian dibandingkan pada masing-masing kelompok. Identifikasi terhadap beberapa faktor-faktor lain yang mempengaruhi diare dilakukan untuk menghindari faktor perancu. Status gizi dikelompokkan sesuai z score, status sosial ekonomi berdasarkan kriteria BPS, dan status higiene sanitasi sesuai indikator higenitas Kementrian Kesehatan RI tahun 2005.

\section{Hasil}

Pengamatan pasca rawat inap dilakukan pada 77 subjek dalam studi I, namun hanya 75 subjek dapat dilakukan pengamatan selama 3 bulan. Dua orang subyek dikeluarkan dari penelitian karena pindah keluar kabupaten Semarang dan tidak dapat dilakukan kunjungan rumah. Karakteristik subjek tertera pada Tabel 1.

Selama 3 bulan pengamatan, didapatkan 26 orang $(34,7 \%)$ dari seluruh subyek yang mengalami diare kembali pasca suplementasi. Kelompok dengan suplementasi seng dan probiotik secara bersamaan mengalami diare berulang, lebih sedikit dibanding kelompok lainnya. Distribusi kejadian diare berulang masing-masing kelompok tertera pada Tabel 2 .

Sebagian besar subyek tinggal dalam wilayah kota Semarang, beberapa anak tinggal di daerah periurban. Sebaran pasien diare berdasarkan tempat tinggal tertera pada Gambar 1.

Meskipun diketahui ada perbedaan rerata, namun uji log rank dengan metode Kaplan Meier tanpa memperhitungkan faktor umur, status gizi, pendidikan pengasuh, riwayat pemberian ASI, status sosial ekonomi, dan status higiene sanitasi, rerata survival tidak berbeda bermakna secara statistik $(\mathrm{p}=0,892)$. Rerata survival tiap kelompok tertera pada Gambar 2.

Tabel 1. Karakteristik subyek penelitian

\begin{tabular}{lccccccccc}
\hline Karakteristik & \multicolumn{3}{c}{ Terapi baku } & \multicolumn{2}{c}{ Seng } & \multicolumn{3}{c}{ Probiotik } & \multicolumn{3}{c}{ Seng-probiotik } & Nilai p \\
\cline { 2 - 9 } & $\mathrm{n}=19$ & $(\%)$ & $\mathrm{n}=19$ & $(\%)$ & $\mathrm{n}=19$ & $(\%)$ & $\mathrm{n}=18$ & $(\%)$ & \\
\hline Jenis kelamin & & & & & & & & & \\
$\quad$ Laki-laki & 9 & 47,4 & 13 & 68,4 & 9 & 47,4 & 10 & 55,6 & $0,518^{*}$ \\
$\quad$ Perempuan & 10 & 52,6 & 6 & 31,6 & 10 & 52,6 & 8 & 44,4 & \\
Kelompok umur (bulan) & & & & & & & & & \\
$\quad$ 6-12 & 15 & 78,9 & 17 & 89,5 & 13 & 68,4 & 10 & 55,6 & $0,113^{*}$ \\
$\quad$ 13-24 & 4 & 21,1 & 2 & 10,5 & 6 & 31,6 & 8 & 44,4 & \\
Riwayat ASI & & & & & & & & & \\
$\quad$ Tanpa ASI & 8 & 42,1 & 10 & 52,6 & 6 & 31,6 & 4 & 22,2 & $0,330^{*}$ \\
$\quad$ ASI + formula & 8 & 42,1 & 6 & 31,6 & 12 & 60,0 & 12 & 62,3 & \\
$\quad$ ASI eksklusif & 3 & 15,8 & 3 & 15,8 & 1 & 8,4 & 2 & 14,5 & \\
Status gizi & & & & & & & & & \\
$\quad$ Baik & 15 & 78,9 & 17 & 89,5 & 16 & 84,2 & 15 & 83,3 & $0,852^{*}$ \\
$\quad$ Kurang & 4 & 21,1 & 2 & 10,5 & 3 & 15,8 & 3 & 16,7 & \\
$\quad$ Pendidikan pengasuh & 15 & 78,9 & 16 & 84,2 & 17 & 89,5 & 14 & 77,8 & $0,770^{*}$ \\
$\quad$ Lulus pendidikan dasar & 4 & 21,1 & 3 & 15,8 & 2 & 10,5 & 4 & 22,2 & \\
Tidak lulus pend. dasar & & & & & & & & & \\
Status sosial ekonomi & & & & & & & & & \\
$\quad$ Mendekati miskin & 14 & 73,7 & 13 & 68,4 & 13 & 31,6 & 15 & 83,3 & $0,596^{*}$ \\
$\quad$ Miskin & 5 & 26,3 & 6 & 31,6 & 6 & 68,4 & 3 & 16,7 & \\
Status higiene sanitasi & & & & & & & & & \\
$\quad$ Kurang baik & 10 & 52,6 & 6 & 31,6 & 6 & 31,6 & 2 & 11,1 & $0,062^{*}$ \\
$\quad$ Baik & 9 & 47,4 & 13 & 68,4 & 13 & 68,4 & 16 & 88,9 & \\
\hline
\end{tabular}


Hani Purnamasari dkk: Pengaruh suplementasi seng dan probiotik terhadap kejadian diare berulang

Tabel 2. Distribusi subyek yang mengalami diare berulang berdasarkan kelompok perlakuan

\begin{tabular}{lccccc}
\hline Asupan dan kadar seng & Terapi baku & $\begin{array}{c}\text { Terapi baku }+ \\
\text { Seng } \\
\mathrm{n}=19(\%)\end{array}$ & $\begin{array}{c}\text { Terapi baku }+ \\
\text { probiotik } \\
\mathrm{n}=19(\%)\end{array}$ & $\begin{array}{c}\text { Terapi baku }+ \text { Seng- } \\
\text { probiotik } \\
\mathrm{n}=18(\%)\end{array}$ & Nilai p \\
\hline Rerata asupan seng & $4,1(1,5)$ & $4,4(1,7)$ & $3,9(1,8)$ & $4,5(1,8)$ & $0,710^{* *}$ \\
Rerata kadar seng serum & $186,3(63,6)$ & $170,3(49,4)$ & $185,3(1,7)$ & $192,6(43,0)$ & $0,581^{* *}$ \\
Kejadian diare berulang & $7(37)$ & $7(37)$ & $7(37)$ & $5(28)$ & \\
\hline
\end{tabular}

** Chi square

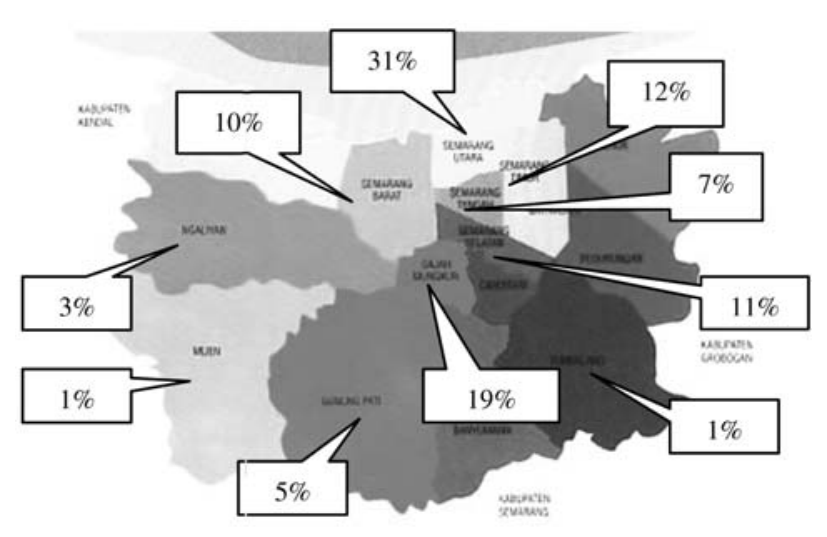

Gambar 1. Persebaran diare berdasarkan tempat tinggal

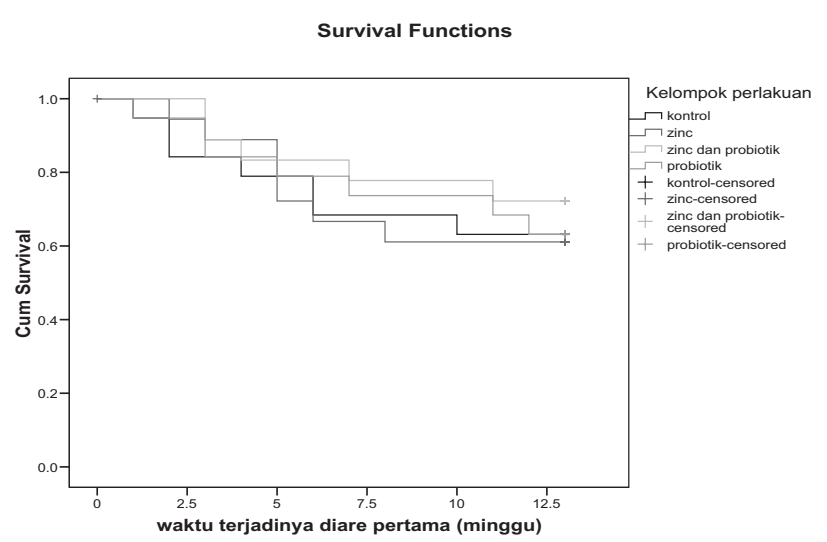

Gambar 2. Grafik survival diare setelah suplementasi

Selanjutnya dilakukan uji cox regression untuk mengetahui peran faktor perancu terhadap kejadian diare berulang. Analisis melibatkan faktor umur, status gizi, pendidikan pengasuh, riwayat pemberian ASI, status sosial ekonomi, dan status higiene sanitasi didapatkan hasil tidak bermakna $(\mathrm{p}=0,556)$, dapat disimpulkan
Tabel 3. Razio hazard diare berulang setelah suplementasi sesuai model cox regression berdasarkan kelompok perlakuan

\begin{tabular}{lcc}
\hline Faktor risiko & $\begin{array}{c}\text { Rasio } \\
\text { hazard }\end{array}$ & CI 95\% \\
\hline $\begin{array}{l}\text { Sosial ekonomi miskin } \\
\text { Pemberian ASI ekslusif }\end{array}$ & 0,51 & $0,16-1,56$ \\
$\begin{array}{l}\text { Status gizi kurang saat } \\
\text { awal sakit }\end{array}$ & 0,69 & $0,28-1,68$ \\
$\begin{array}{l}\text { Status higiene sanitasi } \\
\quad \text { kurang baik }\end{array}$ & 3,04 & $0,66-14,03$ \\
$\begin{array}{l}\text { Umur 6-12 bulan } \\
\begin{array}{l}\text { Pengasuh tidak lulus } \\
\text { pendidikan dasar }\end{array}\end{array}$ & 1,32 & $0,51-3,44$ \\
& 1,35 & $0,94-5,88$ \\
\hline
\end{tabular}

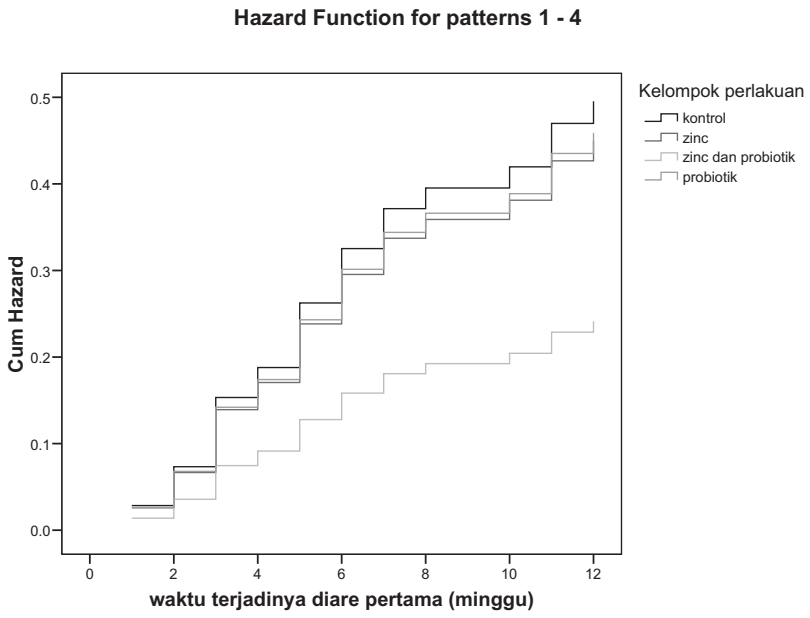

Gambar 3. Grafik hazard function masing-masing kelompok

seluruh kovariat tidak bermakna terhadap kejadian diare berulang. Tidak didapatkan keadaan defisiensi seng pada seluruh subyek. Rerata asupan seng selama tiga bulan pengamatan di bawah nilai normal asupan seng yang dianjurkan. Penyakit penyerta tidak dilaporkan pada keseluruhan subyek selama tiga bulan pengamatan. 
Pada Tabel 4, diare paling sering terjadi pada kelompok yang hanya mendapatkan terapi baku $(0,58$ kali) di bulan pertama. Pada bulan kedua, kelompok dengan terapi baku dan suplementasi seng, tersering mengalami diare, namun tidak didapatkan diare pada bulan ketiga. Kelompok dengan terapi baku tersering mengalami diare pada bulan ketiga. Keempat kelompok tidak berpengaruh secara bermakna terhadap frekuensi diare berulang selama bulan pertama, kedua dan ketiga dengan uji kruskal-wallis.

Pada Tabel 5, kelompok yang mendapatkan terapi baku mengalami diare lebih lama dibandingkan

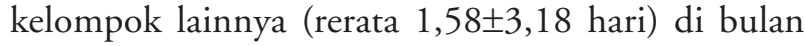
pertama. Sedangkan bulan kedua, kelompok terapi baku dengan suplementasi seng mengalami diare terlama dibandingkan kelompok-kelompok lain (rerata 1,79 $\pm 3,19$ hari). Pada bulan ketiga terjadi penurunan rerata lama diare pada keempat kelompok bila dibandingkan dengan bulan-bulan sebelumnya. Kelompok dengan terapi baku dan suplementasi seng tidak mengalami diare berulang. Tidak didapatkan perbedaan pengaruh keempat kelompok terhadap lama diare pada bulan pertama, kedua maupun ketiga.

\section{Pembahasan}

Kejadian diare berulang dapat merupakan suatu infeksi menetap oleh karena proses penyembuhan tidak sempurna, infeksi baru oleh patogen lain, atau intoleransi makanan akibat fungsi usus yang belum kembali sempurna. ${ }^{4}$ Peran imunitas pada kejadian diare berulang sangatlah penting. Rerata umur saat pertama kali mengikuti penelitian adalah $(11,20 \pm 4,02)$ bulan dengan umur termuda 6 bulan dan tertua 24 bulan. Rerata umur pada penelitian ini lebih tinggi dibandingkan penelitian Agustina ${ }^{23}$ di Indonesia, yaitu $(8,1 \pm 2,6)$ bulan. Hasil survei angka kesakitan diare oleh KEMKES tahun 2000, umur 5-14 bulan merupakan kelompok tertinggi kasus diare. Hal tersebut berhubungan dengan sistem imunologik intestinal dan kemampuan cadangan regenerasi sel epitel usus, selain fungsi organ lain yang masih terbatas pada bayi. Pada umur 6-24 bulan, jumlah air susu ibu sudah mulai berkurang dan pemberian makanan sapih yang kurang nilai gizinya serta nilai kebersihannya. ${ }^{24}$ Subyek pada penelitian kami mayoritas adalah kelompok umur 6-12 bulan, hanya $26,7 \%$ berusia $>1$ tahun.

Tabel 4. Frekuensi diare pada bulan pertama, kedua dan ketiga

\begin{tabular}{lccc}
\hline \multirow{2}{*}{ Kelompok } & Bulan ke- 1 & Bulan ke-2 & Bulan ke-3 \\
\cline { 2 - 4 } & Rerata \pm SB & Rerata \pm SB & Rerata \pm SB \\
\hline Terapi baku & $0,58 \pm 1,170$ & $0,26 \pm 0,806$ & $0,21 \pm 0,918$ \\
Terapi baku+ seng & $0,37 \pm 0,895$ & $0,63 \pm 1,116$ & $0,0 \pm 0,00$ \\
Terapi baku + probiotik & $0,32 \pm 0,749$ & $0,26 \pm 0,806$ & $0,16 \pm 0,501$ \\
Terapi baku + seng + probiotik & $0,39 \pm 0,916$ & $0,11 \pm 0,471$ & $0,17 \pm 0,707$ \\
$\mathrm{p}^{*}$ & 0,862 & 0,290 & 0,581 \\
\hline
\end{tabular}

*uji Kruskal-Wallis

Tabel 5. Lama diare pada bulan pertama, kedua, dan ketiga

\begin{tabular}{lccc}
\hline \multirow{2}{*}{ Kelompok } & Bulan ke-1 & Bulan ke-2 & Bulan ke-3 \\
\cline { 2 - 4 } & Rerata \pm SB & Rerata \pm SB & Rerata \pm SB \\
\hline Terapi baku & $1,58 \pm 3,185$ & $0,89 \pm 2,726$ & $0,47 \pm 2,065$ \\
Terapi baku + Seng & $0,84 \pm 2,544$ & $1,79 \pm 3,190$ & $0,0 \pm 0,00$ \\
Terapi baku + Probiotik & $1,05 \pm 2,505$ & $0,79 \pm 2,371$ & $0,42 \pm 1,427$ \\
Terapi baku +Seng + probiotik & $1,28 \pm 3,025$ & $0,33 \pm 1,414$ & $0,56 \pm 2,357$ \\
p* & 0,927 & 0,267 & 0,582 \\
\hline
\end{tabular}

* uji Kruskal-Wallis 
Pemberian ASI ekslusif adalah salah satu cara mencegah diare karena dapat melindungi saluran cerna dari infeksi dan intoleransi. Selain efek imunitas, pemberian ASI secara tidak langsung membatasi pajanan terhadap makanan/minuman yang terkontaminasi kuman. ${ }^{25}$ Sebagian besar subyek mendapatkan PASI disamping ASI, hanya $12,1 \%$ dengan ASI ekslusif selama 6 bulan. Tidak didapatkan perbedaan bermakna antar kelompok berdasarkan riwayat pemberian ASI, sehingga riwayat ASI ekslusif sebagai faktor perancu pada penelitian ini dapat disingkirkan.

Higiene-sanitasi buruk berakibat masuknya bakteri secara berlebihan ke dalam usus dan mengalahkan pertahanan tubuh normal, berakibat tumbuh lampau bakteri. ${ }^{26}$ Keterbatasan sosial ekonomi berpengaruh terhadap kepadatan lingkungan tempat tinggal, penyediaan sumber air bersih, keadaan higiene sanitasi lingkungan yang berhubungan dengan proses transmisi infeksi enterik, khususnya pada negara berkembang. Tingkat pendidikan orang tua berpengaruh terhadap perilaku dan pola hidup, maka pendidikan pengasuh lebih berperan. ${ }^{27}$ Sosial-budaya mempengaruhi perilaku hidup sehat dan kebersihan diri dan kemudian berperan dalam mengurangi masuknya patogen usus. ${ }^{28}$ Sebuah pengamatan tentang perilaku higiene (misalnya minum air matang dan cuci tangan) di Brazil melaporkan anak-anak dengan perilaku higiene positif berisiko lebih jarang mengalami diare (RR 2,22 CI 95\%: 1,752,81). ${ }^{29}$ Pengelompokan higiene-sanitasi berdasarkan indikator higienitas Departemen Kesehatan RI tahun 2005, dikatakan baik apabila memenuhi 4 dari 10 indikator kesehatan lingkungan yaitu tersedianya jamban, ventilasi yang cukup, terdapat akses air bersih, dan aliran pembuangan. Berdasarkan hal tersebut, subyek sebagian besar termasuk dalam kelompok higiene-sanitasi baik. Dasar pengelompokan belum menyentuh aspek higiene-sanitasi perseorangan, misalnya cara pemakaian botol susu, proses penyiapan makanan, kebiasaan cuci tangan, kebersihan rumah, dan hal lain memungkinkan status higiene-sanitasi menjadi tidak bermakna terhadap kejadian diare berulang.

Kerusakan mukosa usus terjadi pada diare disebabkan oleh invasi dan kerusakan oleh bakteri secara langsung serta efek toksin bakteri pada permukaan epitel. Pada infeksi rotavirus, kesembuhan rata-rata terjadi dalam 2-4 minggu sesudah infeksi, namun dapat berlanjut hingga 4-8 minggu pada bayi di bawah usia 6 bulan. ${ }^{5}$ Pada beberapa anak, diare menetap disebabkan penyembuhan villi tidak sempurna, terutama pada epitel bayi di mana pemulihan seluler lambat. ${ }^{30}$ Suplementasi seng maupun probiotik mempengaruhi derajat kerusakan mukosa, baik secara langsung atau tidak. Pada penelitian ini tidak dilakukan pemeriksaan histopatologi mukosa usus untuk menilai derajat kerusakan mukosa yang terjadi.

Kami tidak mendapatkan perbedaan kejadian diare berulang setelah suplementasi yang dilakukan saat perawatan di rumah sakit pada keempat kelompok. Hal ini berbeda dengan penelitian sebelumnya yang menunjukkan adanya efek positif suplementasi seng. Baqui dkk, ${ }^{31}$ di Bangladesh melaporkan insiden diare yang lebih rendah 15\% pada kelompok yang diberikan seng. Penelitian Bhandari $\mathrm{dkk}^{13}$ memberikan suplementasi seng pada anak umur 6 bulan - 3 tahun selama empat bulan di daerah miskin perkotaan di India didapatkan penurunan kejadian diare. Penelitian di Indramayu, pada 719 bayi dengan suplementasi seng menunjukkan insiden diare selama enam bulan pengamatan lebih rendah dibandingkan kelompok Fe atau Fe dan Seng bersamaan. ${ }^{14}$ Perbedaan tersebut mungkin disebabkan karena penelitian sebelumnya berbasis komunitas. Penelitian kami melakukan pengamatan pada subyek yang sebelumnya dirawat di rumah sakit karena diare cair akut sehingga memungkinkan adanya perbedaan derajat sakit dibandingkan penelitian berbasis komunitas. Beberapa penelitian yang menunjukkan insiden diare lebih rendah pada kelompok seng adalah penelitian di tingkat komunitas dengan jumlah subyek yang besar. Penelitian kami merupakan lanjutan penelitian sebelumnya, dan subyek dihitung sesuai dengan jumlah sampel minimal, tidak dilakukan penghitungan ulang jumlah sampel.

Kadar seng serum dipengaruhi oleh banyak faktor, antara lain masukan dari diet, suplementasi seng, dan kehilangan seng melalui diare. Suplementasi seng akan memperbaiki fungsi sel imun, termasuk hipersensitivitas tipe lambat dan meningkatkan jumlah limfosit CD4 (helper). Suplementasi seng akan bermakna dalam meningkatkan imunitas pada keadaan defisiensi seng sebelumnya. Banyaknya seng yang diabsorpsi berkisar antara $15 \%-40 \%$, tergantung pada status seng dalam serum. Absorpsi seng akan lebih efisien pada seseorang dengan status seng rendah dibanding pada status seng tinggi. ${ }^{32}$ Semua subyek memiliki kadar seng serum normal pada saat awal pengamatan, tidak didapatkan adanya defisiensi seng. Hal tersebut dapat menjadi 
alasan mengapa hasil tidak bermakna, kemungkinan karena suplementasi seng yang diberikan menjadi kurang efektif pada keadaan tanpa defisiensi seng.

Tubuh mempunyai kemampuan untuk memelihara homeostasis seng dalam keadaan diet dengan kandungan seng rendah maupun tinggi. Asupan seng normal pada manusia berkisar antara $107-$ $231 \mathrm{~mol} / \mathrm{hari}$ (6-15 mg/hari). Asupan seng kurang dari $10 \mathrm{mg} / \mathrm{kg}$ atau lebih dari $15 \mathrm{mg} / \mathrm{kg}$ akan membuat mekanisme homeostatik tidak cukup untuk memelihara kandungan seng tubuh, sehingga terjadi zinc loss atau akumulasi seng dalam tubuh. ${ }^{33}$ Telah dilakukan penilaian asupan seng selama pengamatan, didapatkan rerata asupan seng $(4,26 \pm 1,71) \mathrm{mg} / \mathrm{hari}$, di bawah normal. Zinc loss dapat disebabkan oleh asupan seng rendah dan pengeluaran seng berlebihan akibat diare. Ruel ${ }^{34}$ melaporkan bahwa anak diare akut yang dirawat di rumah sakit terjadi kehilangan seng 6,08 mikrogram $/ \mathrm{kgBB} / \mathrm{jam}$. Pemberian seng secara oral dapat menggantikan pengeluaran seng selama diare. Penelitian Baqui ${ }^{32}$ di India mendapatkan hasil peningkatan konsentrasi seng serum setelah suplementasi sehingga mempertahankan status seng dalam masa penyembuhan. Pemeriksaan seng pasca suplementasi dilakukan untuk mengetahui kadar seng serum pasca suplementasi, namun didapatkan kesulitan dalam pengambilan sampel darah subyek. Sebagian besar orang tua subyek menolak untuk pengambilan darah ulang, sehingga kadar seng pasca suplementasi tidak dapat dianalisis. Zinc loss berlebihan akibat asupan rendah dan kehilangan karena diare, dapat menjadi penyebab mengapa hasilnya tidak seperti yang diharapkan.

Pemberian probiotik terbukti bermanfaat pada pengelolaan diare dalam beberapa penelitian terdahulu. Probiotik mencegah diare melalui beberapa mekanisme, antara lain memproduksi substansi antimikrobial, berkompetisi nutrisi untuk pertumbuhan patogen, berkompetisi dalam menghambat ikatan patogen dengan mukosa usus, memodifikasi reseptor toksin atau antitoksin, serta menstimulasi respon sistem imun spesifik dan non spesifik. McFarland $\mathrm{dkk}^{20}$ dalam suatu studi metaanalisis menyimpulkan bahwa probiotik efektif dalam mencegah diare (RR 0,39, 95\% CI 0,27$0,55)$. Kami mendapatkan pemberian probiotik tidak berperan dalam mencegah diare berulang, meskipun rerata waktu timbulnya diare berulang relatif lebih lama daripada kelompok yang hanya diberikan terapi baku. Pemilihan subyek dengan usia lebih muda pada penelitian memungkinkan adanya perbedaan hasil, karena dengan usia muda terdapat perbedaan pada imunitas.

Berdasarkan efek positif pada pemberian seng dan probiotik, dipikirkan untuk pemberiannya secara bersamaan. Penelitian sebelumnya, dengan pemberian diet susu formula disertai penambahan fortifikasi seng dan probiotik, terbukti menurunkan durasi diare, namun tidak melaporkan tentang insiden diare. ${ }^{22,23}$ Kami memberikan preparat seng dan probiotik dalam bentuk suplementasi, dapat menjadi alasan mengapa tidak terdapat perbedaan rerata survival diare, meskipun didapatkan rerata yang lebih lama dibandingkan kelompok yang lain. Bentuk fortifikasi mungkin lebih mudah diabsorpsi, tidak terjadi interaksi bila dua elemen terdapat pada produk makanan atau dalam keadaan diet ligand. ${ }^{19}$

Untuk mengetahui frekuensi dan lama diare, beberapa orang petugas secara bergantian melakukan kunjungan rumah setiap dua minggu sekali. Kejadian diare didapatkan berdasarkan laporan orang tua atau pengasuh. Timbulnya diare berulang masih mungkin tidak dilaporkan oleh orang karena lupa atau alasan lain, meskipun telah diberikan lembaran pemantauan harian yang telah diedukasikan sebelumnya. Selain itu, adanya perubahan perilaku pada orang tua dan pengasuh baik sebagai hasil edukasi selama perawatan di rumah sakit atau karena orang tua atau pengasuh mengetahui anak sebagai subyek penelitian, dapat menurunkan kejadian diare berulang pasca suplementasi.

Berdasarkan tempat tinggalnya subyek terbanyak tinggal di wilayah Semarang Utara, berbeda dengan data profil kesehatan kota Semarang tahun 2007. Kasus diare pada balita terbanyak ditemukan di kecamatan Genuk. Letak RS Dr. Kariadi di kecamatan Gajah Mungkur sehingga memungkinkan subyek berasal dari kecamatan sekitarnya lebih banyak dibawa ke RS Dr. Kariadi. Selain itu, subyek hanya kasus diare yang memerlukan rawat inap. Kecamatan Semarang Utara berada di kawasan perkampungan nelayan, padat penduduk dan sering terkena rob, sehingga berpengaruh terhadap higiene sanitasi, terutama dalam pengadaan air bersih.

Terdapat beberapa keterbatasan pada penelitian, karena tidak dapat dilakukan pemeriksaan histopatologi mukosa usus, sehingga tidak dapat menilai derajat kerusakan mukosa akibat diare. Analisis kadar seng pasca suplementasi tidak dapat dilakukan 
pada semua anak karena orang tua menolak untuk pengambilan darah pasca pengamatan. Keterbatasan lain adalah tidak memeriksa fungsi imun secara subyektif. Pemeriksaan fungsi PMN, sel NK, jumlah INF $\gamma$, jumlah komplemen, jumlah limfosit $T$ dan $B$ serta rasio CD4:CD8 dapat memperkirakan status imunitas. Pemeriksaan tersebut diperlukan mengingat baik seng dan probiotik dapat mempengaruhi status imunitas. Dilain pihak, ditemukan banyak sekali faktor perancu. Perhitungan besar sampel seharusnya memperhitungkan faktor perancu yang ada, yaitu 10 subyek mewakili 1 faktor perancu. Sebagai penelitian lanjutan, hanya mengikuti subyek sesuai perhitungan besar sampel minimal pada studi I, dan tidak menghitung ulang besar sampel minimal.

\section{Kesimpulan}

Pemberian suplementasi seng-probiotik bersamaan berpengaruh dalam memberikan rerata perlindungan terhadap terjadinya diare berulang lebih lama. Tidak terdapat perbedaan dalam rerata diare berulang pertama kali, lama dan frekuensi diare berulang di antara keempat kelompok. Perlu dilakukan penelitian dengan subyek lebih banyak untuk melihat pengaruh suplementasi seng dan probiotik terhadap kejadian diare berulang pasca suplementasi. Pengukuran kadar seng tubuh pasca suplementasi tanpa pengambilan darah misalnya dengan pemeriksaan kadar seng rambut perlu dipertimbangkan pada penelitian selanjutnya, disamping pengukuran fungsi imun (jumlah sel PMN, jumlah limfosit T dan B, rasio CD4 : CD8, kadar IL-1 dan IL-2).

\section{Daftar pustaka}

1. Departemen Kesehatan RI. Profil Kesehatan Indonesia 2003. Jakarta: Departemen Kesehatan RI; 2005.

2. Widaya IW, Gandi. Konsistensi pelaksanaan program serta morbiditas dan mortalitas diare di era ekonomi dan krisis. Disampaikan pada Kongres nasional II Badan Koordinasi Gastroenterologi Anak Indonesia (BKGAI); 3-5 Juli 2003; Bandung,.

3. Dinas kesehatan kota Semarang. Profil Kesehatan Kota Semarang 2007, Pemerintah Kota Semarang, Dinas Kesehatan Kota Semarang, hal. 27. (Diunduh 11 Juni 2008). Didapat dari: URL:http://www.dinkes-kota

\section{semarang.go.id/}

4. Walker-Smith J. Postenteritis diarrhea. Dalam: E lebenthal, editor. Textbook of gastroenterology and nutrition in infancy. New York: Raven Press, Ltd; 1989. h. 1171-86.

5. Lebenthal E. Prolonged small intestinal mucosal injury as a primary cause of intractable diarrhea. New York : Raven Press; 1984.h. 5-27.

6. WHO. The treatment of diarrhea, a manual for physicians and other senior health workers. $4^{\text {th }}$ rev. Geneva, Switzerland : WHO Document Production Services, 2006.

7. Tim Pendidikan Medik Pemberantasan Diare (PMPD). Buku ajar diare. Jakarta: Departemen Kesehatan RI; 1999: 3-14.

8. WHO. Implementing the new recommendations on the clinical management of diarrhea, guidelines for policy makers and programme managers. Geneva, Switzerland: WHO Document Production Services, 2006.

9. Juffrie M. Diare persisten. Dalam : Modul pelatihan diare. Edisi pertama. UKK Gastro-Hepatologi Jakarta: Badan Penerbit IDAI; 2009.h. 29-45.

10. Fontaine O. Evidence for the safety and Evidence for the safety and efficacy of zinc supplementation in the management of diarrhea. Sari pediatri 2008: 14-20.

11. Lukacik M, Thomas RL, Aranda JV. A Meta-analysis of the effects of oral zinc in the treatment of acute and persistent diarrhea. Pediatrics 2008;121;326-36

12. Hidayat A. The effect of zinc supplementation in children under three years of age with acute diarrhoea in Indonesia. Med J Indones 1998;7:237-41.

13. Bhandari N. Substantial reduction in severe diarrheal morbidity by daily zinc supplementation in young north indian children. Pediatrics 2002;109; 86

14. Endang-Purwaningsih. A community-based randomized controlled trial of iron and zinc supplementation in indonesian infants : effect on child morbidities. MMI 2005;40:52-60

15. Patel A, Dibley MJ, Mamtani1 M, Badhoniya1 N, Kulkarni H. Zinc and copper supplementation in acute diarrhea in children: a double-blind randomized controlled trial. BMCMedicine, (in press). (Diunduh pada 19 Mei 2009). Didapat dari: http //www.physorg.com/ news $160724065 . \mathrm{html}$

16. Szajewska H. Probiotics and prebiotics in pediatric: where are we now? Turkish J pediatrics 2007;49:23144

17. Michael de Vrese, Marteau, PR. Probiotics and prebiotics: effects on diarrhea. J Nutr 2007; 137: S803-S11. 
18. Saavedra JM, Bauman NA, Oung I, Perman JA, Yolken RH. Feeding of Bifidobacterium bifidum and streptococcus thermophilus to infant in hospital for prevention of diarrhea and shedding of rotavirus. Lancet 1994;344:1046-9.

19. Sazawal, Hiremath G, Dhingra U, Malik P, Deb S, Black R. Efficacy of probiotics in prevention of acute diarrhoea: a meta-analysis of masked, randomised, placebo-controlled trials. The Lancet Infect Dis 2006; 6:374-82.

20. McFarland LV, Elmer Gindian W, McFarland M. Metaanalysis of probiotics for the prevention and Treatment of acute pediatric diarrhea. Int J Probiotics and Prebiotics 2006;1:63-76.

21. Van Niel CW, Feudtner C, Garrison MM, Christakis DA. Lactobacillus therapy for acute infectious in children: A meta-analysis. J Pediatr 2002;109:678-84.

22. Shamir R, Makhoul IR, Etzioni A, Shehadeh N. Evaluation of a diet containing probiotics and zinc the treatment of mild diarrheal illness in children younger than one year of age. J Am Coll Nutr 2005: 370-5.

23. Agustina R. The effect of early nutritional supplementation with a mixture of probiotic, prebiotic, fiber and micronutrients in infant with acute diarrhea in Indonesia. Asia Pac J Clin Nutr 2007;16:435-42.

24. Sudigbia I. Pengaruh suplementasi tempe terhadap kecepatan tumbuh pada penderita diare anak umur 6-24 bulan. Disertasi. Universitas Diponegoro, 1990:7-37.

25. Arifeen S, Black RE, Antelman G, Baqui A, Caulfield Becker S. Exclusive breastfeeding reduces acute respiratory infection and diarrhea deaths among infant in Dhaka slums. Pediatrics 2001;108;e67

26. Riedel BD, Ghishan FK. Acute Diarrhea. Dalam: Pediatric Gastrointestinal disease: pathophysiology, diagnosis, management. Edisi ke-2. St Louis Missouri: Mosby;1996. h. 251-62.

27. Adisasmito W. Faktor risiko diare pada bayi dan balita di indonesia: systematic review penelitian akademik bidang kesehatan masyarakat. Makara Kes 2007;11:1-10.

28. Adisasmito W. Faktor risiko diare pada bayi dan balita di Indonesia: systematic review penelitian akademik bidang kesehatan masyarakat. Makara kesehatan 2007;11:110 .

29. Strina A, Cairncross S, Barreto M.L, Larrea C, Prado MS. Childhood diarrhea and observed hygiene behavior in Salvador Brazil. Am J Epidemiol 2003;157:1032-8.

30. Fisher RG, Boyce TG. Gastrointestinal syndromes. Dalam : Moffet's pediatric infectious diseases a problemoriented approach. Edisi ke-4. Philadelphia: Lippincott Williams \& Wilkins;2005. h.420-43.

31. Baqui AH. Effect of zinc supplementation started during diarrhea on morbidity and mortality in Bangladeshi children: community randomized trial. BMJ 2002;325:1059.

32. Baqui AH, Black RE, Walker CLF, Arifeen S, Zaman K. Zinc supplementation and serum zinc during diarrhea. Indian J Pediatr 2006;73:493-7.

33. King JC, Shames DM, Woodhouse LR. Zinc homeostasis in human. J Nutr 2000;130:1360S-S6.

34. Artana WD, Suraatmaja S, Aryasa KN, Suandi IKG. Peran suplementasi mineral mikro seng terhadap kesembuhan diare. Sari pediatri 2005;1:15-8. 